\title{
Anther and Pollen Morphology and Anatomy in Walnut (Juglans regia L.)
}

\author{
Cevriye Mert \\ Uludag University Faculty of Agriculture, Department of Horticulture, \\ Görükle Campus 16059, Bursa, Turkey
}

Additional index words. anther, Juglans regia L., morphology, pollen, SEM, TEM, ultrastructure

\begin{abstract}
The morphology and ultrastructure of anthers and pollen grains were described for eight walnut (Juglans regia L.) cultivars (Şebin, Bilecik, Kaman I, Kaplan 86, Yalova 3, Pedro, Hartley, and Franquette) using light microscopy and scanning and transmission electron microscopy. Anther and pollen dimensions and pollen production capabilities were also determined. The mean number of stamens per staminate flower (14.90 to 20.03) and mean anther dimensions (1412.5 to $2553.5 \mu \mathrm{m}$ in length and 849.0 to $1145.5 \mu \mathrm{m}$ in width) differed significantly among the cultivars. The number of pollen grains per anther also varied significantly and ranged from 4720 to 9840 among the cultivars. The pollen grains of walnut plants are spherical in shape (nearly circular) and pantocolporate (with many colporate apertures on the exine). The pollen surface is microechinate with spiniferous projections. The germination pores are circular and nonbordered. Pollen grain length varied from 33.35 to $37.50 \mu \mathrm{m}$ in the examined cultivars. The ultrastructure of the pollen walls was similar between walnut cultivars. The exine was comprised of nexine and sexine, which was thicker than the underlying nexine. The sexine appeared as a strong tectum that was traversed by thin channels and decorated with spinulose processes. The thicknesses of the various layers of the pollen wall were as follows: intine: 82.1 to $200 \mathrm{~nm}$; exine: 793.1 to $1161.1 \mathrm{~nm}$; and total wall: 954.4 to $1327.8 \mathrm{~nm}$.
\end{abstract}

Juglans regia L. is typical of Juglandaceae in that it is monoecious, wind-pollinated, and self-compatible. Despite its self-compatibility, breeding and research programs have encountered difficulties acquiring sufficient quantities of pollen when the pistillate flowers are receptive because of the dichogamous nature of the species, which has both protandrous and protogynous mating types (Luza and Polito, 1985). The leaves and blossoms of the walnut tree normally appear in the spring. Staminate flowers are borne on catkins, usually 10 to $15 \mathrm{~cm}$ in length, which emerge from lateral buds on the wood from the previous season's growth. Catkin length, the number of flower clusters per catkin, and the number of flowers per cluster are variable among walnut species and between genotypes within a given species. Each catkin may produce as many as two million pollen grains (Forde, 1981).

The pollen grains have a definite shape, size, color, and structure for each species, genus, and family, and these characters are useful for systematic botany. Therefore, the structural characteristics of the pollen grains from many fruit species have been described by researchers (Arzani et al., 2005; Currie et al., 1997; Fogle, 1977a, 1977b; Martens

Received for publication 1 Feb. 2010. Accepted for publication 11 Mar. 2010.

I thank Professor Dr. Arif Soylu for critical review of the manuscript and helpful suggestions during the study. I thank Professor Dr. Ilkin Cavusoglu for valuable support during TEM and Professor Dr. Cengiz Baycu for valuable support during the SEM studies.

e-mail cevmert@uludag.edu.tr. and Fretz, 1980; Mert, 2009; Mert and Soylu, 2007; Westwood and Challice, 1978). Although there have been some descriptions of pollen morphology in Juglandaceae (Stone et al., 1964; Ueno, 1975; Whitehead, 1963), studies of walnut are sparse. Colzoni et al. (1990) described the pollen wall ultrastructure of Juglans regia and Juglans nigra. Evrenosoglu and Misirlı (2009) determined pollen morphology and pollen size in 'Kaplan 86' and 'Şebin' walnut cultivars. Luza and Polito (1988) examined anther differentiation, microsporogenesis, and pollen development in $J$. regia. So far, few detailed ultrastructural studies on the cellular organization of the walnut anther and mature pollen have been published. These studies will promote a better understanding of the reproductive biology of walnut cultivars and may identify characteristics of taxonomic and phylogenetic interest. In this study, the anatomical structure of the anther and pollen grains of several walnut cultivars were determined. Anther and pollen dimensions and pollen production capabilities were also studied.

\section{Materials and Methods}

Plant materials. The study was conducted on the following walnut cultivars: Şebin, Bilecik, Kaman I, Kaplan 86, Yalova 3, Pedro, Hartley, and Franquette.

Dimensions of the anthers and pollen grain. An ocular micrometer (BH-2; Olympus Optical Co., Tokyo, Japan) was used to measure the dimensions of 50 anthers and 50 pollen grains. In addition, length:width ratios were calculated, and shape indices were determined according to Erdtman (1966).
Determination of the pollen production per anther. The amount of pollen production per anther was determined using the hemacytometric method (Mert and Soylu, 2007).

Light microscopy and transmission electron microscopy. Before the staminate flowers began to shed their pollen, sample flowers were fixed in FAA solution (10 formalin:5 glacial acetic acid:50 ethanol:35 water, by volume) and washed three times in phosphate buffer (pH 7.2) for $20 \mathrm{~min}$. Then the anthers were fixed in $1 \%$ osmium tetroxide for $2 \mathrm{~h}$, dehydrated in a graded ethanol series $(50 \%, 70 \%$, $95 \%$, and twice with a $100 \%$ ), embedded in Spurr's epoxy resin, and sectioned $(1 \mu \mathrm{m})$ using an ultramicrotome (Reichert Supernova; Leica, Vien, Austria). Anther sections were stained with $1 \%$ toluidine blue and examined under a BH-2 LM (Olympus Optical Co.). All photographs were taken using an Olympus DP 20 camera.

To study the ultrastructure of the pollen and the pollen wall, the materials were thinsectioned. Thin sections (90 to $100 \mathrm{~nm}$ thick) were stained with uranyl acetate and lead citrate. Sections were observed under a JSM1220 transmission electron microscope (TEM) (Jeol, Tokyo, Japan).

Measurements of the exine and intine layers of the pollen wall were made using TEM with an "image measuring system" and expressed in units of nanomolars. The thickness of the exine, intine, and total pollen wall were determined for 10 pollen grains at three different regions for each grain.

Scanning electron microscopy. After dehydration, the anthers and pollen grains were mounted on scanning electron microscopy (SEM) stubs, coated with gold-palladium (Polaron SC7620; VG Microtech, Uckfield, UK), and examined with a JSM-5600 LV SEM (Jeol).

Statistical analysis. The data were analyzed using MSTAT-C statistical software (Version 2.1; Michigan State University, East Lansing, MI), and means were compared using Duncan's multiple range test $(P \leq 0.05)$.

\section{Results and Discussion}

Anther morphology and dimensions. Walnut is a monoecious fruit species, and the catkins form a spike-like structure (Abbe, 1974). The number of the stamens per staminate flower is presented in Table 1 . The mean number of stamens per staminate flower ranged from 14.90 to 20.03 and varied significantly between cultivars. Sütyemez (2007) noted that the number of stamens per flower varied from 17 to 22. Similarly Molina et al. (1996) found that the number of stamens per flower ranged from 12.9 to 15.5 . Although our results were somewhat different from the previously published reports, they are generally in the same range as the earlier measurements. Anther dimensions were also significantly different among the cultivars (Table 1). 'Bilecik' $(1145.5 \mu \mathrm{m})$ has the widest anthers, and 'Kaman I' (2553.5 $\mu \mathrm{m})$ has the longest anthers. Both values were significantly lower in 'Franquette' $(849.0 \mu \mathrm{m}$, 
Table 1. The mean stamen number of the staminate flower, number of pollen grain per anther, dimensions of anther, and length/width ratios in walnut (Juglans regia L.) cultivars.

\begin{tabular}{|c|c|c|c|c|c|c|}
\hline Cultivar & $\begin{array}{c}\text { Stamen } \\
\text { (no./flower) }\end{array}$ & $\begin{array}{l}\text { Pollen grain } \\
\text { (no./anther) }\end{array}$ & $\begin{array}{l}\text { Anther length (L) } \\
{[\text { mean } \pm \mathrm{SE}(\mu \mathrm{m})]}\end{array}$ & $\begin{array}{l}\text { Anther width }(\mathrm{W}) \\
{[\mathrm{mean} \pm \mathrm{SE}(\mu \mathrm{m})]}\end{array}$ & $\begin{array}{c}\text { Length:width } \\
\text { ratio } \\
\end{array}$ & Anther shape \\
\hline Şebin & $18.73 \pm 1.99 \mathrm{bc}^{z}$ & $6720{b c^{2}}^{2}$ & $1885.0 \pm 144.2 \mathrm{e}^{\mathrm{z}}$ & $945.5 \pm 66.8 \mathrm{~cd}^{\mathrm{z}}$ & $1: 99$ & Prolate \\
\hline Kaplan 86 & $16.16 \pm 1.20 \mathrm{~d}$ & $7920 \mathrm{ab}$ & $2463.5 \pm 156.4 \mathrm{~b}$ & $980.5 \pm 121.4 \mathrm{c}$ & $2: 51$ & Perprolate \\
\hline Yalova 3 & $20.00 \pm 1.36 \mathrm{a}$ & $7280 \mathrm{abc}$ & $2082.0 \pm 171.3 \mathrm{~d}$ & $1032.5 \pm 76.1 \mathrm{~b}$ & $2: 02$ & Perprolate \\
\hline Kaman I & $14.90 \pm 1.29 \mathrm{e}$ & $9840 \mathrm{a}$ & $2553.5 \pm 213.6 \mathrm{a}$ & $978.5 \pm 101.1 \mathrm{c}$ & 2:61 & Perprolate \\
\hline Pedro & $18.06 \pm 0.58 \mathrm{c}$ & $4720 \mathrm{c}$ & $1412.5 \pm 121.0 \mathrm{f}$ & $872.5 \pm 74.4 \mathrm{e}$ & $1: 62$ & Prolate \\
\hline Hartley & $20.03 \pm 1.18 \mathrm{a}$ & $6800 \mathrm{bc}$ & $2161.5 \pm 128.4 \mathrm{c}$ & $938.5 \pm 55.1 \mathrm{~d}$ & $2: 30$ & Perprolate \\
\hline
\end{tabular}

${ }^{2}$ Mean values followed by different lower-case letters different significantly by Duncan's multiple range test at $P \leq 0.05$.

$1871.5 \mu \mathrm{m})$ compared with the other cultivars (Table 1). Anthers of all the cultivars are of the perprolate and prolate types in shape.

The stamen consists of two morphologically distinct parts: the anther and the filament. Anthers of walnut cultivars have four microsporangia arranged in pairs of two lobes; each pair is separated by parenchymatous and vascular tissue at the connective site of the anther (Fig. 1A, C) as described by Luza and Polito (1988). The tissues surrounding the anther consist of a surface epidermis, endothecium, middle layers, and a tapetum (Fig. 1B). The mature walnut pollen sac contains pollen grains and a new completely collapsed tapetum (Fig. 1A, C, D).

Significant differences were observed in walnut cultivars with respect to the number of pollen grains in each anther. The pollen number per anther varied from 4720 to 9840 among the cultivars (Table 1). Sütyemez (2007) found that the pollen number per anther ranged from 6126 to 7502 . Our results support this finding.

Pollen surface morphology and dimensions. The pollen grains in all of the examined walnut cultivars were spherical (nearly circular) and pantocolporate (Fig. 2A-B). The pollen is circular in polar view (Fig. 2A) and suboblate in equatorial view (Fig. 2B). The pollen surface is microechinate with spiniferous projections (Fig. 2C). At anthesis, the pollen grains, which are not fully hydrated, are collapsed at the polar ends (Fig. 2D). The germination pores are circular and nonbordered (Fig. 2C). Evrenosoglu and Misirlı (2009) obtained similar results and stated that the pollen grains of walnut cultivars were pantocolporate and nearly circular (spherical).

The pollen grains from the cultivars used in this study have been shown to vary significantly with respect to diameter when measured along their length (polar) and width (equatorial) and ranged from 33.35 to 37.50 $\mu \mathrm{m}$ and from 39.30 to $43.15 \mu \mathrm{m}$, respectively (Table 2). This is consistent with the findings of previous researchers (Evrenosoglu and Misırl1, 2009; Molina et al., 1996). However, walnut pollen grains are also larger than those measured in other nut species such as chestnut (Castanea sativa Mill.), 9 to $21 \mu \mathrm{m}$ (length $\times$ width) (Beyhan and Serdar, 2009; Bounous et al., 1992; Mert and Soylu, 2007), and pistachio (Pistacia atlantica Desf., Anacardiaceae), 33.7 to $37.2 \mu \mathrm{m}$ (length $\times$ width) (Belhadj et al., 2007). Pollen grains from the examined walnut cultivars have a suboblate
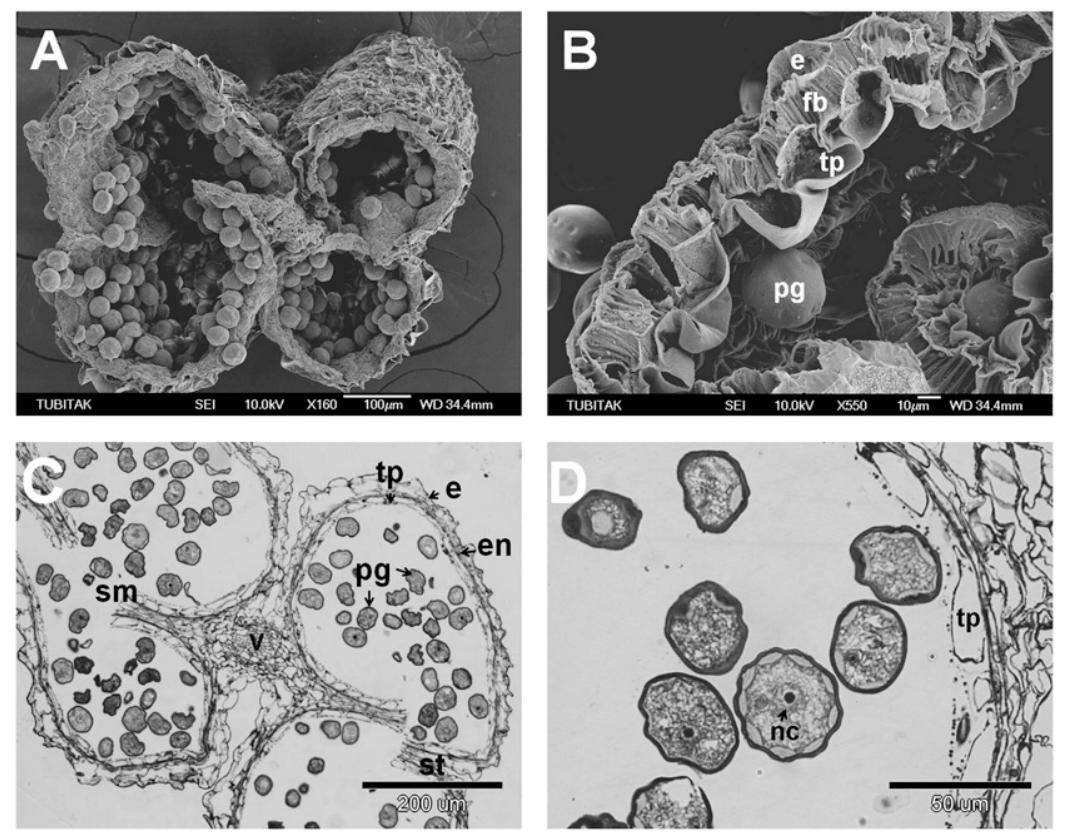

Fig. 1. Scanning electron micrographs of external anther morphology of 'Hartley' whole anther $(\mathrm{bar}=100 \mu \mathrm{m})$ (A) and anther wall (bar $=10 \mu \mathrm{m})(\mathbf{B})$. Transverse section of four locules in a 'Franquette' anther stained with toluidine blue and photographed using light microscopy (bar $=200 \mu \mathrm{m})(\mathbf{C})$. Mature pollen grains at anthesis in 'Pedro' $($ bar $=50 \mu \mathrm{m})(\mathbf{D}) . \mathrm{e}=$ epidermis; en = endothecium; fb = fibrous band; $\mathrm{nc}=$ nucleus; $\mathrm{pg}=$ pollen grain; $\mathrm{sm}=$ septum; $\mathrm{st}=$ stomium; $\mathrm{tp}=$ tapetum; $\mathrm{v}=$ vascular region.
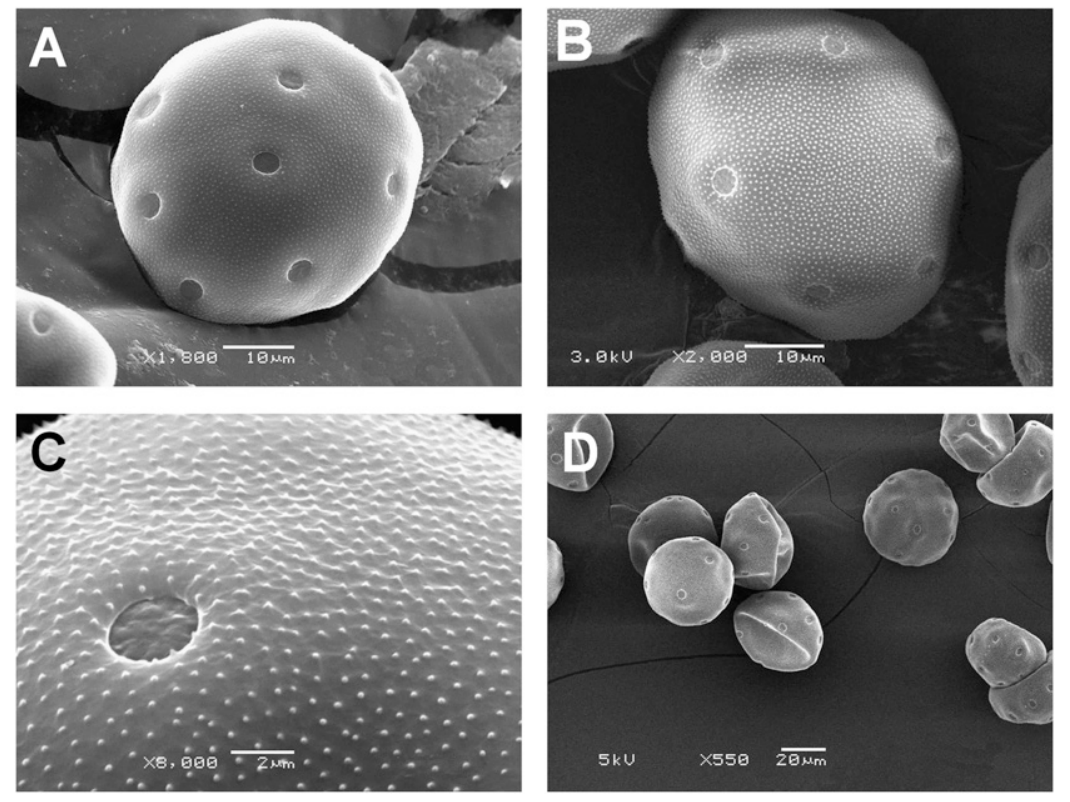

Fig. 2. Scanning electron micrographs of pollen grains. Circular is polar view (A) and suboblate is equatorial view (B) in 'Bilecik'. Germ pore and microechinate wall and sculpturing of pollen in 'Bilecik' (C). Collapsed polar view in 'Hartley' (D). 
Table 2. Dimensions of pollen grains together with length:width ratios and shapes in walnut (Juglans regia L.) cultivars.

\begin{tabular}{lcccr}
\hline Cultivar & $\begin{array}{c}\text { Pollen length } \\
{[\text { mean } \pm \text { SE }(\mu \mathrm{m})]}\end{array}$ & $\begin{array}{c}\text { Pollen width } \\
{[\text { mean } \pm \mathrm{SE}(\mu \mathrm{m})]}\end{array}$ & $\begin{array}{c}\text { Length:width } \\
\text { ratio }\end{array}$ & Shape \\
\hline Şebin & $36.80 \pm 1.89 \mathrm{a}^{\mathrm{z}}$ & $42.45 \pm 1.78 \mathrm{a}^{\mathrm{z}}$ & $0: 87$ & Suboblate \\
Kaplan 86 & $34.75 \pm 1.83 \mathrm{~b}$ & $41.25 \pm 1.90 \mathrm{a}$ & $0: 84$ & Suboblate \\
Yalova 3 & $37.50 \pm 1.82 \mathrm{a}$ & $43.05 \pm 2.16 \mathrm{a}$ & $0: 87$ & Suboblate \\
Bilecik & $37.40 \pm 1.67 \mathrm{a}$ & $43.15 \pm 2.51 \mathrm{a}$ & $0: 87$ & Suboblate \\
Kaman I & $34.25 \pm 2.03 \mathrm{bc}$ & $40.65 \pm 2.24 \mathrm{bc}$ & $0: 84$ & Suboblate \\
Pedro & $35.00 \pm 2.08 \mathrm{~b}$ & $41.10 \pm 2.32 \mathrm{bc}$ & $0: 85$ & Suboblate \\
Hartley & $33.35 \pm 1.64 \mathrm{~d}$ & $40.20 \pm 2.25 \mathrm{c}$ & $0: 83$ & Suboblate \\
Franquette & $33.95 \pm 1.89 \mathrm{~cd}$ & $39.30 \pm 2.20 \mathrm{~d}$ & $0: 86$ & Suboblate \\
\hline
\end{tabular}

${ }^{\mathrm{z}}$ Mean values followed by different lower-case letters different significantly by Duncan's multiple range test at $P \leq 0.05$.

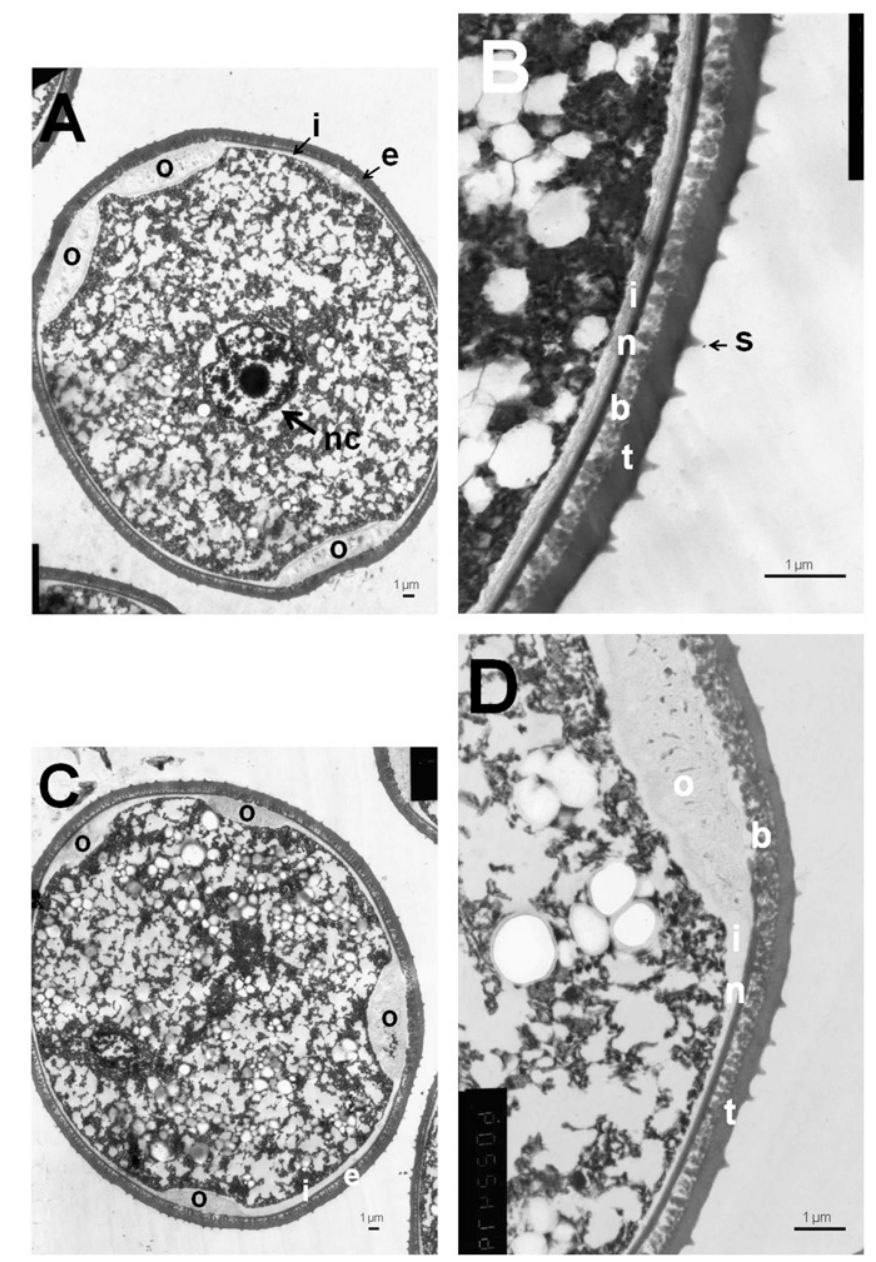

Fig. 3. Transmission electron micrographs (TEM) of pollen grain and pollen wall in walnut cultivars Pedro (A-B) and Kaman I (C-D). Transverse section (1.500×) through pollen grain showing cytoplasm, vacuole, starch granules and oncus $(\mathbf{A}, \mathbf{C})(\mathrm{bar}=1 \mu \mathrm{m})$. Transverse section $(10,000 \times$ and $6,000 \times)$ of pollen wall showing tectum, bacula, nexine, intine, and spines $(\mathbf{B}, \mathbf{D})(\mathrm{bar}=1 \mu \mathrm{m}) ; \mathrm{b}=$ bacula; $\mathrm{e}=$ exine; $\mathrm{i}=$ intine; $\mathrm{n}=$ nexine; $\mathrm{nc}=$ nucleus; $\mathrm{o}=$ oncus; $\mathrm{s}=$ spines; $\mathrm{t}=$ tectum.

Table 3. Intine, exine, and total wall (exine + intine) thickness of pollen grains in walnut (Juglans regia L.) cultivars.

\begin{tabular}{lccc}
\hline Cultivar & $\begin{array}{c}\text { Intine thickness } \\
{[\text { mean } \pm \mathrm{SE}(\mathrm{nm})]}\end{array}$ & $\begin{array}{c}\text { Exine thickness } \\
{[\text { mean } \pm \mathrm{SE}(\mathrm{nm})]}\end{array}$ & $\begin{array}{c}\text { Intine }+ \text { exine thickness } \\
{[\text { mean } \pm \mathrm{SE}(\mathrm{nm})]}\end{array}$ \\
\hline Sebin & $155.5 \pm 98.8 \mathrm{ab}^{\mathrm{z}}$ & $1055.6 \pm 129.7 \mathrm{a}^{\mathrm{z}}$ & $1211.1 \pm 189.8 \mathrm{a}^{\mathrm{z}}$ \\
Kaplan 86 & $200.0 \pm 120.6 \mathrm{a}$ & $1111.1 \pm 111.3 \mathrm{a}$ & $1311.1 \pm 213.4 \mathrm{a}$ \\
Yalova 3 & $166.6 \pm 107.3 \mathrm{ab}$ & $1161.1 \pm 146.2 \mathrm{a}$ & $1327.8 \pm 192.2 \mathrm{a}$ \\
Bilecik & $161.8 \pm 50.8 \mathrm{ab}$ & $793.1 \pm 66.5 \mathrm{~b}$ & $954.4 \pm 101.4 \mathrm{~b}$ \\
Kaman I & $125.0 \pm 35.1 \mathrm{bc}$ & $844.4 \pm 121.7 \mathrm{~b}$ & $969.4 \pm 121.8 \mathrm{~b}$ \\
Pedro & $161.1 \pm 44.5 \mathrm{ab}$ & $816.7 \pm 166.1 \mathrm{~b}$ & $977.8 \pm 166.6 \mathrm{~b}$ \\
Hartley & $82.1 \pm 35.3 \mathrm{c}$ & $895.6 \pm 198.5 \mathrm{~b}$ & $977.6 \pm 209.3 \mathrm{~b}$ \\
Franquette & $132.8 \pm 36.4 \mathrm{abc}$ & $853.3 \pm 123.4 \mathrm{~b}$ & $992.2 \pm 125.0 \mathrm{~b}$ \\
\hline
\end{tabular}

${ }^{2}$ Mean values followed by different lower-case letters are different significantly by Duncan's multiple range test at $P \leq 0.05$. shape (Table 2) similar to the pecan and pistachio (Belhadj et al., 2007; Wetzstein and Sparks, 1986).

Anatomical structure of the pollen grains. The walnut microspore was comprised of a nucleus and various cytoplasmic organelles that were relatively sparse (Fig. 3A, C). The pollen grain wall consisted of two layers: the outer exine layer and the inner intine layer (Fig. 3A-D). The appearance of the cross-sections of the pollen walls was similar between walnut cultivars. The exine was comprised of sexine, which is thicker than the underlying nexine; the former appeared as a strong tectum that was traversed by thin channels and decorated by spinulose processes as shown by Colzoni et al. (1990). The bacula was more sparse and without lamellar structure (Fig. 3B, D). The nexine was less abruptly interrupted in the proximity of the pores, which were also without opercula (Fig. 3A, C, D). Additionally, the intine was spread throughout the oncus (Fig. 3D). The intine is often noticeably irregular in thickness and permeated by cytoplasmic channels. The stratification of the walnut cultivars' pollen wall is similar to those described for J. regia (Colzoni et al., 1990) and pecan (Yates and Sparks, 1992).

Measurements of the thickness of the pollen wall layers are given in Table 3. The thicknesses of the intine, exine, and total wall of the pollen grains were significantly different among the cultivars. Total wall (exine + intine) and exine thickness was thickest in 'Yalova 3', 'Kaplan 86' and 'Şebin'. The intine layer was thickest in the cultivar Kaplan $86(200.0 \mathrm{~nm})$ and thinnest in 'Hartley' $(82.1 \mathrm{~nm})$.

\section{Literature Cited}

Abbe, A.C. 1974. Flowers and inflorescences of the 'Amentiferae'. Bot. Rev. 40:159-261.

Arzani, K., M.A. Nejatian, and G. Karimzadeh 2005. Apricot (Prunus armeniaca) pollen morphological characterisation through scanning electron microscopy, using multivariate analysis. N. Z. J. Crop Hort. Sci. 33:381-388.

Belhadj, S., A. Derridj, L. Civeyrel, C. Gers, T. Aigouy, T. Otto, and T. Gauquelin. 2007. Pollen morphology and fertility of wild Atlas pistachio (Pistacia atlantica Desf., Anacardiaceae). Grana 46:148-156.

Beyhan, N. and S. Serdar. 2009. In vitro pollen germination and tube growth of some European chestnut genotypes (Castanea sativa Mill.). Fruits 64:157-165.

Bounous, G., R. Paglietta, and C. Peano. 1992. Methods for observing chestnut pollen viability, germinability and pollen tube growth. Proc. Int. Chestnut Conf., Morgantown, WV.p.76-78

Colzoni, G.L., A. Speranza, R. Caramiello, G. Piccone, and P. Zannini. 1990. Wall ultrastructure and biochemical features of the Juglans regia L. and Juglans nigra L. male gametophyte. Sex. Plant Reprod. 3:139-146.

Currie, A.J., D.A. Noiton, G.S. Lawes, and D. Bailey. 1997. Preliminary results of differentiating apple sports by pollen ultrastructure. Euphytica 98:155-161.

Erdtman, G. 1966. Pollen morphology and plant taxonomy: Angiosperms. Hafner Publishing Company, New York, NY. 
Evrenosoglu, Y. and A. Misirl1. 2009. Investigations on the pollen morphology of some fruit species. Turk. J. Agr. For. 33:181-190.

Fogle, H.W. 1977a. Identification of clones within four tree fruit species by pollen exine patterns. J. Amer. Soc. Hort. Sci. 102:552560.

Fogle, H.W. 1977b. Identification of tree fruit species by pollen ultrastructure. J. Amer. Soc. Hort. Sci. 102:548-551.

Forde, H.I. 1981. Persian walnuts in the western United States, p. 84-97. In: Jaynes, R.A. (ed.). Nut tree culture in North America. 2nd Ed. The Northern Nut Growers Assoc. Inc., Hamden, CT.

Luza, J.G. and V.S. Polito. 1985. In vitro germination and storage of English walnut pollen. Sci. Hort. 27:303-316.

Luza, J.G. and V.S. Polito. 1988. Microsporogenesis and anther differentiation in Juglans regia
L.: A developmental basis for heterodicogamy in walnut. Bot. Gaz. 149:30-36.

Martens, J. and T.A. Fretz. 1980. Identification of eight crabapples by pollen surface sculpture. J. Amer. Soc. Hort. Sci. 105:257-263.

Mert, C. 2009. Pollen morphology and anatomy of cornelian cherry (Cornus mas L.) cultivars. HortScience 44:519-522.

Mert, C. and A. Soylu. 2007. Morphology and anatomy of pollen grains from male-fertile and male-sterile cultivars of chestnut (Castanea sativa Mill.). J. Hort. Sci. Biotechnol. 82:474-480.

Molina, R.T., A.M. Rodriguez, I.S. Palacios, and F.G. Lopez. 1996. Pollen production in anemophilous trees. Grana 35:38-46.

Stone, D.E., J. Reich, and S. Whitfield. 1964. Fine structure of the walls of Juglans and Carya pollen. Pollen Spores 6:379-392.

Sütyemez, M. 2007. Determination of pollen production and quality of some local and foreign walnut genotypes in Turkey. Turk. J. Agr. For. 3:109-114.

Ueno, J. 1975. The fine structure of pollen surface VI. Amentiferae. Rep. Fac. Sci. Shizuoka Univ. 10:109-118.

Westwood, M.N. and J.S. Challice. 1978. Morphology and surface topography of pollen and anthers of Pyrus species. J. Amer. Soc. Hort. Sci. 103:28-37.

Wetzstein, H.Y. and D. Sparks. 1986. Flowering in pecan. Hort. Rev. (Amer. Soc. Hort. Sci.) 8:217-255.

Whitehead, D.R. 1963. Pollen morphology in the Juglandaceae. I. Pollen size and pore number variation. J. Arnold Arbor. Harv. Univ. 44:101110.

Yates, I.E. and D. Sparks. 1992. External morphological characteristics for periods during pecan microspore and pollen differentiation. J. Amer. Soc. Hort. Sci. 117:190-196. 